\title{
Characterization of Borrelia burgdorferi strains isolated from Korea by 165 rDNA sequence analysis and PCR-RFLP analysis of rrf (5S)-rrl (235) intergenic spacer amplicons
}

\author{
Seung-Hyun Lee, ${ }^{1}$ Bum-Joon Kim, ${ }^{1} \dagger$ Jong-Hyun Kim, ${ }^{2}$ Kyung-Hee Park, ${ }^{2}$ \\ Seon-Ju Yeo, ${ }^{1}$ Seo-Jeong $\mathrm{Kim}^{3}$ and Yoon-Hoh Kook ${ }^{1}$
}

Author for correspondence: Yoon-Hoh Kook. Tel: +82 2740 8306. Fax: +8227430881. e-mail: yhkook@plaza.snu.ac.kr

\footnotetext{
1 Department of Microbiology and Institute of Endemic Diseases, Medical Research Center, Seoul National University College of Medicine, and Clinical Research Institute, Seoul National University Hospital, Seoul 110-799, Korea

2 Department of Microbiology, College of Medicine, Kon-Kuk University, Choongju, Choongchungbuk-Do 380-701, Korea

3 Department of Pediatrics, Pundang CHA General Hospital, Pochun CHA University College of Medicine, Sungnam, Kyonggi-Do 463-670, Korea
}

\begin{abstract}
Haenam strains of Borrelia burgdorferi, which had been isolated from Ixodes granulatus and Apodemus agrarius in Haenam, Korea, were characterized by PCR-RFLP analysis of $r r f(5 S)-r r l$ (23S) intergenic spacer amplicons and by sequence analysis of the 16S rRNA gene (rDNA). The Msel and Dral restriction patterns of the 5S-23S intergenic spacer amplicons of Haenam strains differed from those of other $B$. burgdorferi sensu lato strains. Furthermore, in the phylogenetic tree based on the 16S rDNA sequences, Haenam strains formed a distinctive cluster, clearly separated from the other members of B. burgdorferi sensu lato. These results suggest that, apart from Borrelia garinii and Borrelia afzelii, other genotypes of $B$. burgdorferi sensu lato exist in Korea and the Haenam strain is a newly identified one.
\end{abstract}

Keywords: Borrelia burgdorferi, 16S rDNA, $\operatorname{rrf}(5 \mathrm{~S})-\operatorname{rrl}(23 \mathrm{~S})$ intergenic spacer gene, sequence analysis

\section{INTRODUCTION}

Borrelia burgdorferi, the causative spirochaete of Lyme disease, is transmitted to human and animals by Ixodes ticks. Lyme borreliosis now occurs in all parts of the world and is considered to be one of the most prevalent tick-borne infectious diseases in Europe and North America (Steere, 1989). Many Lyme disease spirochaetes have also been isolated in Korea, Japan, China and Russia (Park et al., 1993; Anderson, 1989). Some of them have been classified as new species in the genus Borrelia (Kawabata et al., 1993; Postic et al., 1993; Fukunaga et al., 1996).

\footnotetext{
†Present address: Dept of Microbiology, Cheju National University College of Medicine, Cheju, Korea.

Abbreviation: UPGMA, unweighted pair group method with arithmetic averages.

The GenBank accession numbers for the $55-235$ intergenic spacer sequences and $16 \mathrm{~S}$ rDNA sequences of the Haenam strains are given in the text.
}

Several methods have been used to characterize and identify the causative agents of Lyme disease. These are: protein analysis using monoclonal antibodies (Barbour et al., 1985; Canica et al., 1993), multilocus enzyme electrophoresis (Boerlin et al., 1992), plasmid profiles (Barbour, 1988), 16S rDNA sequence analysis (Marconi \& Garon, 1992) and PCR-RFLP analysis of 5S-23S intergenic spacer amplicons (Postic et al., 1994). Using these methods, B. burgdorferi sensu lato is currently divided into 10 species. These are: $B$. burgdorferi (Johnson et al., 1984), Borrelia afzelii (Canica et al., 1993), Borrelia garinii (Baranton et al., 1992), Borrelia japonica (Kawabata et al., 1993), Borrelia valaisiana (Wang et al., 1997), Borrelia lusitaniae (Le Fleche et al., 1997), 'Borrelia andersonii' (Marconi et al., 1995), Borrelia turdi and Borrelia tanukii (Fukunaga et al., 1996) and 'Borrelia bissettii' (Postic et al., 1998).

Recently we isolated two Borrelia strains from Ixodes granulatus, which is a rare species as tick vector for Lyme spirochaetes, and eight strains from Apodemus agrarius in the Haenam area, Korea. The PCR-RFLP 
patterns of their $5 \mathrm{~S}-23 \mathrm{~S}$ intergenic spacer genes differed from those of the other Korean isolates which had been simultaneously isolated and identified as $B$. afzelii and $B$. garinii. The RFLP patterns of the genomic DNA probed by using the 23S rRNA gene (NheI-PstI and StyI fragments) were also different (Park et al., 1998). In the present study, both PCRRFLP analysis of 5S-23S intergenic spacer amplicons and comparative sequence analysis of $16 \mathrm{~S}$ rDNA were performed for Haenam strains to determine their relationships with known species of the genus Borrelia. We also developed a PCR method for the rapid identification of the Haenam strains based on the $16 \mathrm{~S}$ rDNA sequences.

\section{METHODS}

Bacterial strains and DNA extraction. Ten Haenam strains (HN-6, HN-8, HN-11, HN-12, HN-13, HN-14, HN-15, HN-16, HN-18 and HN-19) were used for the characterization. Two strains ( $\mathrm{HN}-6$ and $\mathrm{HN}-8)$ were isolated from I. granulatus and the others were isolated from $A$. agrarius. Three reference strains (B. burgdorferi $\mathrm{B} 31^{\mathrm{T}}$, B. garinii IP89 and $B$. afzelii VS461 ${ }^{\mathrm{T}}$ ) were used for the PCR-RFLP analysis of the $5 \mathrm{~S}-23 \mathrm{~S}$ intergenic spacer amplicon as a direct comparison with the Haenam strains. Also, nine reference strains (B. burgdorferi B31 ${ }^{\mathrm{T}}$, B. garinii IP89, B. afzelii $\mathrm{VS}_{461}{ }^{\mathrm{T}}, B$. japonica $\mathrm{HO}^{\mathrm{T}}{ }^{\mathrm{T}}, B$. valaisiana $\mathrm{VS}_{116}{ }^{\mathrm{T}}, B$. lusitaniae PotiB2 $2^{\mathrm{T}}$, 'B. bissettii' $\mathrm{DN} 127^{\mathrm{T}}$, ' $B$. andersonii' 21123 and $B$. hermsii HS1) were used for the specific PCR identification of Haenam strains. These spirochaetes were cultivated at $32^{\circ} \mathrm{C}$ in BSKII medium (Barbour, 1984). DNA was extracted by a modification of the method previously described by Barbour \& Garon (1987). Briefly, a pellet from a $5 \mathrm{ml}$ culture was suspended in $650 \mu \mathrm{l}$ TE $(10 \mathrm{mM}$ Tris pH 8.0, $100 \mathrm{mM}$ EDTA). RNase $\left(10 \mu \mathrm{l}, 10 \mathrm{mg} \mathrm{ml}^{-1}\right)$ and lysozyme $\left(20 \mu \mathrm{l}, 10 \mathrm{mg} \mathrm{ml}^{-1}\right)$ were added to the suspension. After 30 min incubation at $37^{\circ} \mathrm{C}$, SDS $(0.5 \%)$ was added and the suspension further incubated at $65^{\circ} \mathrm{C}$ for $10 \mathrm{~min}$. The DNA was extracted four times with equal volumes of phenol and once with an equal volume of chloroform. The DNA was precipitated by adding $0 \cdot 1$ vol. $3 \mathrm{M}$ sodium acetate and 2 vols absolute ethanol, washed with $70 \%$ ethanol and resuspended in TE $\mathrm{pH} 8 \cdot 0$.

PCR-RFLP analysis of the 5S-23S intergenic spacer. PCR was performed by using a specific primer set (forward, 5'CTGCGAGTTCGCGGGAGA-3'; and reverse, 5'-TCCTAGGCATTCACCATA-3') to amplify $254 \mathrm{bp}$ DNA as described by Postic et al. (1994). Template DNA (50 ng) and 20 pmol of each primer were added to a PCR mixture tube (AccuPower PCR PreMix; Bioneer), which contained $1 \mathrm{U}$ Taq DNA polymerase, $250 \mu \mathrm{M}$ of each dNTP, $50 \mathrm{mM}$ Tris $/ \mathrm{HCl} \mathrm{pH} \mathrm{8.3,} 40 \mathrm{mM} \mathrm{KCl}, 1.5 \mathrm{mM} \mathrm{MgCl}_{2}$ and gel loading dye. The volume was then adjusted to $20 \mu \mathrm{l}$ with distilled water. The reaction mixture was subjected to 30 cycles of amplification $\left(1 \mathrm{~min}\right.$ at $94{ }^{\circ} \mathrm{C}, 1 \mathrm{~min}$ at $52^{\circ} \mathrm{C}$ and 2 min at $72^{\circ} \mathrm{C}$ ) followed by 5 min extension at $72^{\circ} \mathrm{C}$ (PerkinElmer Cetus, model 9600 thermocycler). Endonucleases MseI and DraI (Promega) were used to cleave the PCR products as recommended by the manufacturer. The restriction fragments were electrophoresed on a $16 \%$ acrylamide gel for $3 \mathrm{~h}$ at $100 \mathrm{~V}$.

Nucleotide sequencing of the 5S-23S intergenic spacer gene. The PCR products were electrophoresed on a $2 \%$ agarose

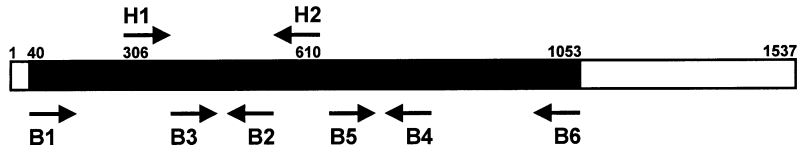

Fig. 1. Primers (B1-B6) used for the amplification of 165 rDNA in this study. $\mathrm{H} 1$ and $\mathrm{H} 2$ are specific primers for Haenam strains.

gel and purified with a QIAEX II Gel Extraction kit (Qiagen). Purified PCR product (20 ng) was ligated with $50 \mathrm{ng}$ pGEM-T vector (Promega) at $16^{\circ} \mathrm{C}$ for $18 \mathrm{~h}$ and used for the transformation of Escherichia coli XL-1 Blue. Recombinant DNA was extracted by using a High Pure Plasmid Isolation kit (Boehringer Mannheim). The purified DNA was sequenced using an Applied Biosystems 373A automatic sequencer and BigDye Terminator Cycle Sequencing kit (PE Applied Biosystems) with forward and reverse sequencing primer (M13) (New England Biolabs). At least two clones were sequenced. For the sequencing reaction, $500 \mathrm{ng}$ purified DNA, $3 \cdot 2 \mathrm{pmol}$ primer and $8 \mu \mathrm{l}$ BigDye Terminator RR mix (PE Applied Biosystems) were mixed, and the final volume adjusted to $20 \mu \mathrm{l}$ by adding distilled water. The reaction was performed using $5 \%(\mathrm{v} / \mathrm{v})$ DMSO for 30 cycles of $15 \mathrm{~s}$ at $95^{\circ} \mathrm{C}, 10 \mathrm{~s}$ at $50^{\circ} \mathrm{C}$ and $4 \mathrm{~min}$ at $60{ }^{\circ} \mathrm{C}$

Nucleotide sequencing of the 16S rRNA gene (rDNA). A primer set [B1 (5'-CAGTGCGTCTTAAGCATGC-3'; position $40-58$ in $B$. burgdorferi $\mathrm{B} 31^{\mathrm{T}}$ ) and $\mathrm{B} 6$ (5'-CAACCATGCAGCACCTGTA-3'; 1053-1035)] was used to amplify $16 \mathrm{~S}$ rDNA (1013 bp). Target DNAs were amplified in a $20 \mu \mathrm{l} \mathrm{PCR}$ mixture tube (AccuPower PCR PreMix; Bioneer). Template DNA (50 ng) and $20 \mathrm{pmol}$ of each primer were added and adjusted to a volume of $20 \mu \mathrm{l}$ with distilled water. The reaction mixture was subjected to 30 cycles of amplification $\left(30 \mathrm{~s}\right.$ at $95^{\circ} \mathrm{C}, 30 \mathrm{~s}$ at $58^{\circ} \mathrm{C}$ and $45 \mathrm{~s}$ at $72{ }^{\circ} \mathrm{C}$ ), followed by $5 \mathrm{~min}$ extension at $72^{\circ} \mathrm{C}$. Cloning and sequencing were carried out by the same method as above except that the sequencing primers used were: B1, B2 (5'CGACCTTCTTCATTCACGC-3'; 416-398), B3 (5'-GCAGCTAAGAATCTTCCGCAATGG-3'; 350-373), B4 (5'AAGTTCGCCTTCGCCTCCGGTA-3'; 735-714), B5 (5'TGTAAGGGTGGAATCTGTTG-3'; 681-700) and B6 (Fig. 1).

Sequence alignment and the phylogenetic tree. Sequences of $16 \mathrm{~S}$ rDNA were aligned using the multiple alignment algorithm in the MegAlign package (Windows version 3.12e; DNASTAR). All positions with alignment gaps were excluded from the pairwise sequence comparison. A phylogenetic tree was constructed using MEGA software (Kumur et al., 1993). UPGMA (unweighted pair group method with arithmetic averages) and neighbour-joining trees were created based on the Jukes-Cantor distance estimation method and pairwise deletion. Bootstrap analysis was performed with 100 replications.

Nucleotide sequence accession numbers. The GenBank accession numbers of the $5 \mathrm{~S}-23 \mathrm{~S}$ intergenic spacer sequences of the Haenam strains are AF058705 (HN-6) and AF058706 (HN-8). The accession numbers of the $16 \mathrm{~S}$ rDNA sequences are AF055416 (HN-6), and AF055418-AF055421 (HN-8, $\mathrm{HN}-14, \mathrm{HN}-19$ and HN-13, respectively). To compare the members of $B$. burgdorferi sensu lato, the 16S rDNA sequences of reference strains available from GenBank were compared with those of the Haenam strains. These were: $B$. 


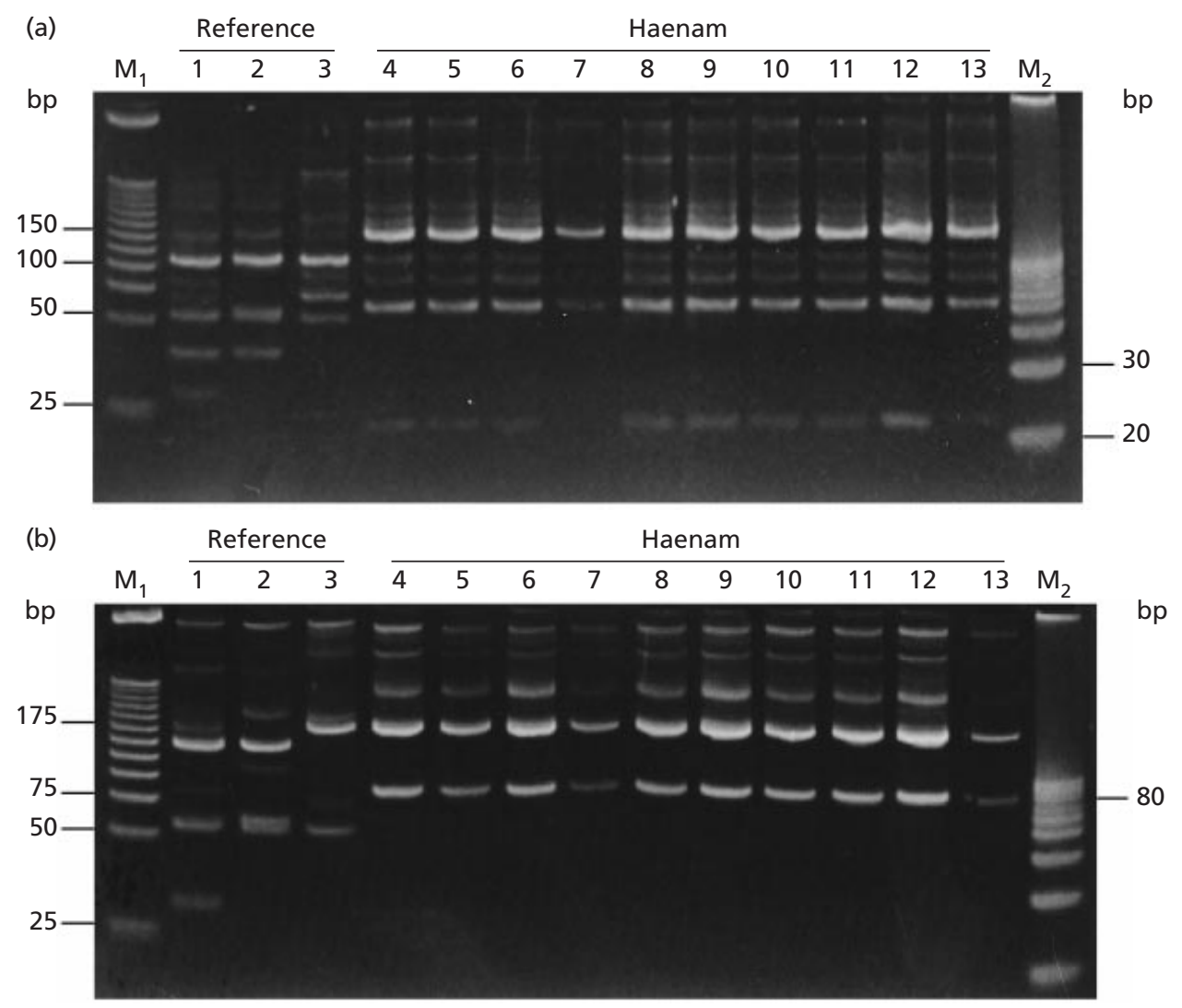

Fig. 2. Msel (a) and Dral (b) restriction patterns of the amplified $55-235$ intergenic spacer DNA fragments from Haenam strains and three $B$. burgdorferi sensu lato strains (B. burgdorferi $\mathrm{B} 31^{\top}, B$. garinii IP89 and $B$. afzelii VS461 ${ }^{\top}$ ). The restriction patterns of the Haenam strains differ from those of the reference strains. Lanes: $M_{1}$, marker DNA (25 bp DNA ladder); 1, B. burgdorferi B31 ${ }^{\top}$; 2, B. garinii IP89; 3, B. afzelii VS461 ${ }^{\top} ; 4, \mathrm{HN}-6 ; 5, \mathrm{HN}-8 ; 6, \mathrm{HN}-11 ; 7, \mathrm{HN}-12 ; 8, \mathrm{HN}-13 ; 9$, $\mathrm{HN}-14 ; 10, \mathrm{HN}-15 ; 11, \mathrm{HN}-16 ; 12, \mathrm{HN}-18 ; 13, \mathrm{HN}-19 ; \mathrm{M}_{2}$, marker DNA (10 bp DNA ladder).

burgdorferi B31 $1^{\mathrm{T}}$ (U03396), B. burgdorferi 297 (X85204), B. garinii $20047^{\mathrm{T}}$ (D67018), B. garinii PBi (X85199), B. afzelii VS461 $^{\mathrm{T}}$ (U78151), B. afzelii HT61 (D67019), B. japonica

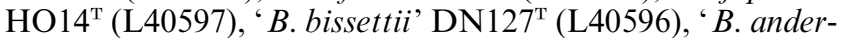
sonii' $21038^{\mathrm{T}}$ (L46701), B. turdi Ya501 (D67022), B. turdi Ac502 (D67024), B. tanukii Hk501 (D67023), B. tanukii OR2eL (D67020), B. lusitaniae PotiB1 (X98226), B. lusitaniae PotiB2 ${ }^{\mathrm{T}}$ (X98228), B. lusitaniae PotiB3 (X98229), B. valaisiana VS116 ${ }^{\mathrm{T}}$ (X98232), B. valaisiana UK (X98233), B. valaisiana Am501 (D67021), B. hermsii HS1 (M60968) and finally $B$. anserina ES-1 (U42284). The 5S-23S intergenic spacer sequences of reference strains available from GenBank were also used for comparison purposes. These were: B. burgdorferi $\mathrm{B} 31^{\mathrm{T}}$ (L30127), B. garinii $20047^{\mathrm{T}}$ (L30119), B. garinii NT29 (L30130), B. afzelii VS461 ${ }^{\mathrm{T}}$ (L30135), $B$. japonica $\mathrm{HO}_{4}^{\mathrm{T}}$ (L30128), B. bissetti DN127 ${ }^{\mathrm{T}}$ (L30126), B. bissetti CA55 (L30124), B. bissetti 25015 (L30122), ' $B$. andersonii' 21133 (L30120), B. turdi Ya501 (D84407), B. tanukii Hk501 (D84404), B. lusitaniae PotiB2T (L30131), B. lusitaniae PotiB3 (L30132), B. valaisiana VS116 ${ }^{\mathrm{T}}$ (L30134), $B$. valaisiana UK (L30133) and B. valaisiana Am501 (D84402).

PCR for the identification of Haenam strains. The $16 \mathrm{~S}$ rDNAs (305 bp) were amplified with the newly designed specific primers for Haenam strains [H1 (5'-GTCACACTGGAACTGAGAC-3'; position 306-324 in B. burgdorferi $\mathrm{B}^{\prime} 1^{\mathrm{T}}$ ) and $\mathrm{H} 2$ (5'-GCTATTTTATGCATAGACTTAC-3';
610-589)] (Fig. 1) in a $20 \mu$ PCR mixture tube (AccuPower PCR PreMix; Bioneer). Template DNA (50 ng) and $20 \mathrm{pmol}$ of each primer were added and the volume adjusted to $20 \mu \mathrm{l}$. The reaction mixture was subjected to 25 cycles of amplification $\left(20 \mathrm{~s}\right.$ at $94{ }^{\circ} \mathrm{C}, 15 \mathrm{~s}$ at $59^{\circ} \mathrm{C}$ and $30 \mathrm{~s}$ at $\left.72^{\circ} \mathrm{C}\right)$, followed by $5 \mathrm{~min}$ extension at $72^{\circ} \mathrm{C}$.

\section{RESULTS}

\section{PCR-RFLP analysis and sequence analysis of the 5S-23S intergenic spacer amplicon}

The 254 bp fragment of 5S-23S intergenic spacer genes was amplified from the Haenam strains and cleaved by two different restriction enzymes, MseI and DraI. The MseI restriction pattern (150, 58, 24 and 22 bp, Fig. 2a) and DraI restriction pattern (173 and 81 bp, Fig. 2b) of Haenam strains were identical, but differed from those of previously reported B. burgdorferi sensu lato strains (Postic et al., 1994, 1998; Masuzawa et al., 1996) (Table 1).

The nucleotide sequences of amplified $5 \mathrm{~S}-23 \mathrm{~S}$ intergenic spacer DNAs (254 bp) from Haenam strains were determined and compared to those of other $B$. burgdorferi sensu lato strains. The sequence similarity of the Haenam strains ranged from $99 \cdot 6$ to $100 \%$ (data 
Table 1. Dral and Msel restriction fragments of 5S-23S intergenic spacer amplicons

\begin{tabular}{|c|c|c|c|}
\hline \multirow[t]{2}{*}{ Strain } & \multirow{2}{*}{$\begin{array}{l}\text { Amplicon } \\
\text { size (bp) }\end{array}$} & \multicolumn{2}{|c|}{ Restriction fragment sizes (bp) with* } \\
\hline & & DraI & MseI \\
\hline B. burgdorferi $\mathrm{B} 31^{\mathrm{T}}$ & 254 & $144,53,29,28$ & $108,51,38,29,28$ \\
\hline \multicolumn{4}{|l|}{ B. garinii } \\
\hline $20047^{\mathrm{T}}$ & 253 & 201,52 & $108,95,50$ \\
\hline NT29 & 253 & $144,57,52$ & $108,57,50,38$ \\
\hline B. afzelii $\mathrm{VS} 461^{\mathrm{T}}$ & 246 & $174,52,20$ & $108,68,50,20$ \\
\hline B. japonica $\mathrm{HO} 14^{\mathrm{T}}$ & 236 & No restriction site & $108,78,50$ \\
\hline 'B. andersonii' 21133 & 266 & No restriction site & $120,67,51,28$ \\
\hline \multicolumn{4}{|l|}{ 'B. bissettii' } \\
\hline $\mathrm{DN} 127^{\mathrm{T}}$ & 257 & $144,53,33,27$ & $107,52,38,33,27$ \\
\hline CA55 & 226 & $144,53,29$ & $107,52,38,29$ \\
\hline 25015 & 253 & $173,53,27$ & $107,52,34,27,17,12,4$ \\
\hline B. turdi Ya501 & 248 & $144,81,23$ & $107,51,38,21,16,8,7$ \\
\hline B. tanukii $\mathrm{Hk} 501$ & 245 & $173,52,20$ & $174,51,20$ \\
\hline B. valaisiana $\mathrm{VS} 116^{\mathrm{T}}$ & 255 & 203,52 & $175,50,23,7$ \\
\hline \multicolumn{4}{|l|}{ B. lusitaniae } \\
\hline PotiB1, PotiB2 ${ }^{\mathrm{T}}$ & 257 & $145,83,29$ & $108,81,39,29$ \\
\hline PotiB3 & 255 & 146,109 & $108,79,52,16$ \\
\hline \multicolumn{4}{|l|}{ Haenam strains } \\
\hline $\mathrm{HN}-6$ & 254 & 173,81 & $150,58,24,22$ \\
\hline $\mathrm{HN}-8$ & 254 & 173,81 & $150,58,24,22$ \\
\hline $\mathrm{HN}-11$ & 254 & 173,81 & $150,58,24,22$ \\
\hline HN-12 & 254 & 173,81 & $150,58,24,22$ \\
\hline $\mathrm{HN}-13$ & 254 & 173,81 & $150,58,24,22$ \\
\hline $\mathrm{HN}-14$ & 254 & 173,81 & $150,58,24,22$ \\
\hline $\mathrm{HN}-15$ & 254 & 173,81 & $150,58,24,22$ \\
\hline HN-16 & 254 & 173,81 & $150,58,24,22$ \\
\hline $\mathrm{HN}-18$ & 254 & 173,81 & $150,58,24,22$ \\
\hline $\mathrm{HN}-19$ & 254 & 173,81 & $150,58,24,22$ \\
\hline
\end{tabular}

* Exact restriction fragment sizes of both Haenam strains and reference strains (Postic et al., 1994, 1998; Masuzawa et al., 1996) were determined from the sequences.

not shown). The sequences of $\mathrm{HN}-6, \mathrm{HN}-14$ and $\mathrm{HN}-$ 19 were identical. The sequences of $\mathrm{HN}-8, \mathrm{HN}-11$, HN-12, HN-13, HN-15, HN-16 and HN-18 strains were also identical and differed by only one nucleotide from the former sequence (HN-6 strain). The sequences of Haenam strains were compared to those of 12 reference strains from GenBank. The sequence similarities of Haenam strains to other strains of $B$. burgdorferi sensu lato were $70 \cdot 1-88 \cdot 2 \%$ (data not shown). Haenam strains showed relatively high similarity $(87.8$ and $88.2 \%)$ with $B$. burgdorferi $\mathrm{B} 31^{\mathrm{T}}$. The sequence similarities of the $5 \mathrm{~S}-23 \mathrm{~S}$ intergenic spacer sequences of Haenam strains to $B$. valaisiana, $B$. lusitaniae and B. tanukii were $71 \cdot 0-85 \cdot 8 \%, 70 \cdot 1-70 \cdot 5 \%$ and $80 \cdot 4-80 \cdot 8 \%$, respectively.

\section{$16 \mathrm{~S}$ rDNA sequence analysis}

The $1013 \mathrm{bp}$ fragment of 16S rDNA from five Haenam strains (HN-6, HN-8, HN-13, HN-14 and HN-19) was amplified and characterized. The sequences were aligned and compared with those of 21 Borrelia reference strains by using the multiple alignment algorithm in the MegAlign package (Windows version 3.12e; DNASTAR). Sequence similarity of the Haenam strains ranged from $99 \cdot 5$ to $100 \%$. In general, they showed $97 \cdot 6-99.5 \%$ similarity with 19 reference strains of B. burgdorferi sensu lato. A particularly high level of similarity of $16 \mathrm{~S}$ rDNA sequences was observed in $B$. valaisiana $(99 \cdot 0-99 \cdot 5 \%), B$. tanukii $(98 \cdot 9-99 \cdot 4 \%)$ and B. lusitaniae (98.7-99.1\%). B. valaisiana was found to be similar to $B$. tanukii $(99 \cdot 0-99 \cdot 6 \%)$.

A phylogenetic tree was constructed by the UPGMA and neighbour-joining methods. In the phylogenetic tree created by the UPGMA method, Haenam strains formed a distinctive cluster, separated from other strains of $B$. burgdorferi sensu lato. Haenam strains were closer to $B$. valaisiana and $B$. tanukii than to $B$. afzelii and $B$. garinii, which had been previously isolated and reported in Korea (Park et al., 1993) (Fig. 


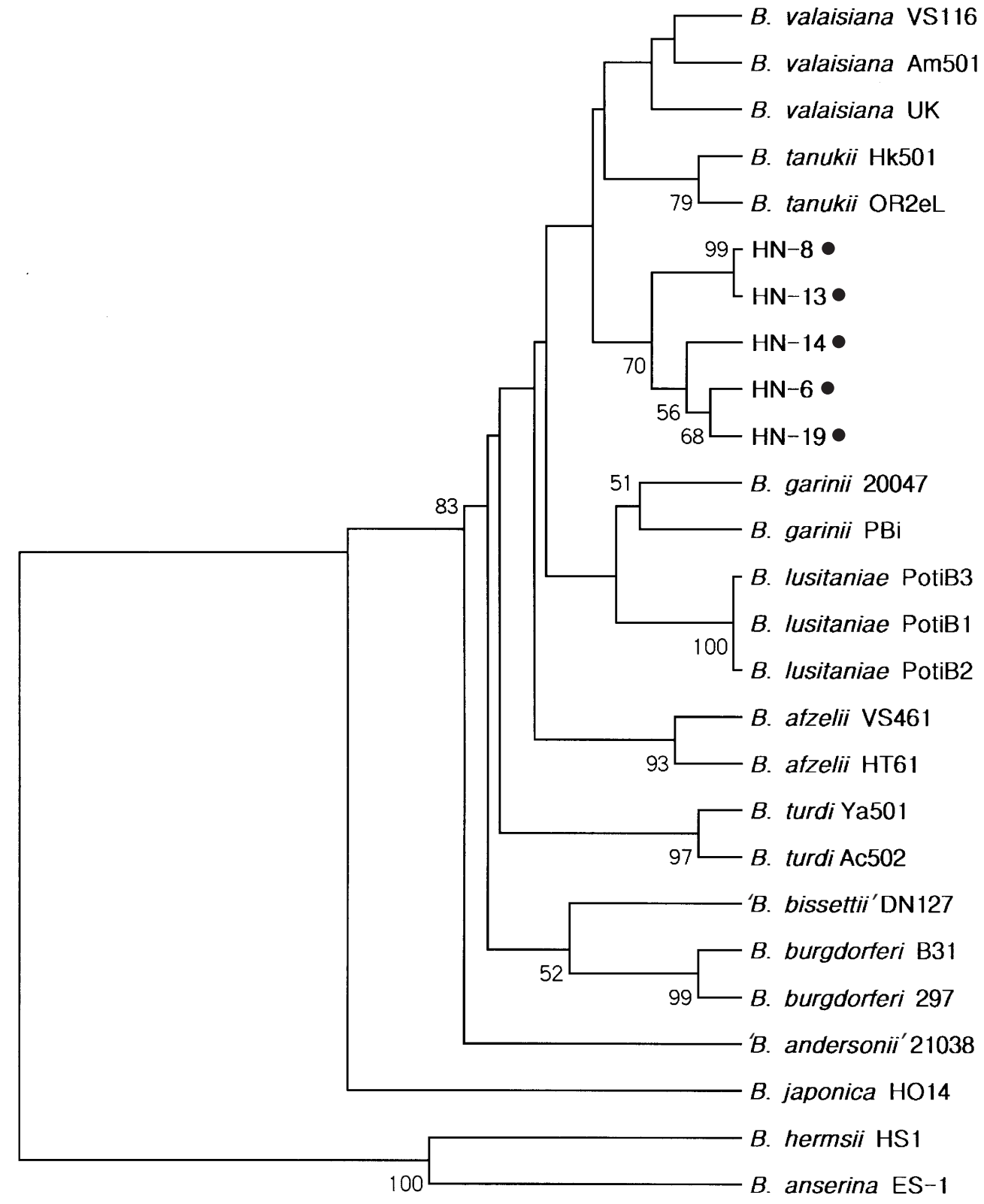

$0.5 \%$

Fig. 3. Phylogenetic tree of $B$. burgdorferi sensu lato strains. The tree was constructed by the UPGMA method using MEGA software. Haenam strains. Bootstrap analysis was performed with 100 replications. The scale bar represents $0.5 \%$ divergence.

3). In the phylogenetic tree created by the neighbourjoining method, Haenam strains again formed a distinctive cluster separated from other strains of $B$. burgdorferi sensu lato (data not shown).

\section{Identification of Haenam strains by PCR}

Three signature nucleotides for Haenam strains in the sequences of 16S rDNA were found. These are C324,
G589 and T836 (numbering of B. burgdorferi $\mathrm{B} 31^{\mathrm{T}}$ ). These nucleotides differentiate Haenam strains from other strains of B. burgdorferi sensu lato. Among these nucleotides, C324 and G589 were used for the specific primers (H1 and H2) to amplify 305 bp DNA from Haenam strains. The targeted PCR products were observed only from the Haenam strains, suggesting that these primers can be used specifically to identify Haenam strains (Fig. 4). 


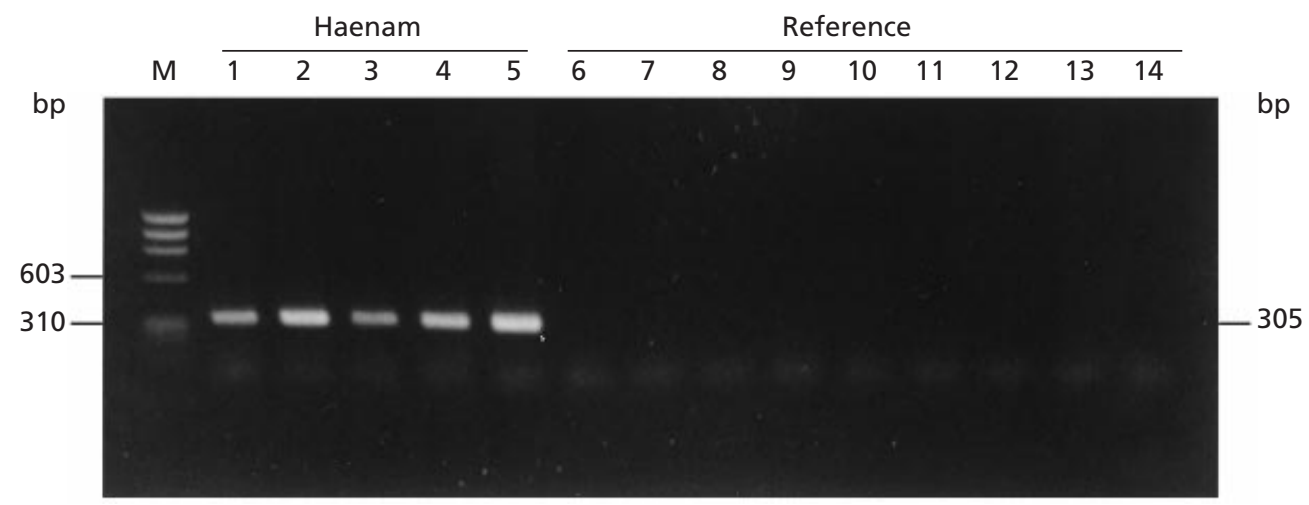

Fig. 4. Amplification of $16 \mathrm{~S}$ rDNA from $B$. burgdorferi sensu lato strains with the Haenam-specific primers ( $\mathrm{H} 1$ and $\mathrm{H} 2)$. The 305 bp DNAs were amplified only from the Haenam strains (lanes 1-5). Lanes: M, marker DNA ( $\phi$ X174/RF DNA/Haelll fragments); 1, HN-6; 2, HN-8; 3, HN-13; 4, HN-14; 5, HN-19; 6, B. burgdorferi B31 ${ }^{\top} ; 7$, B. garinii IP89; 8, B. afzelii VS461 ${ }^{\top}$; 9, B. japonica $\mathrm{HO}^{\top}{ }^{\top}$; 10, B. valaisiana VS116 ${ }^{\top}$; 11, B. lusitaniae PotiB2 ${ }^{\top}$; 12, 'B. bissettii' DN127 ${ }^{\top}$; 13, B. andersonii 21123; 14, B. hermsii HS1.

\section{DISCUSSION}

According to previous reports, among the currently recognized species of the genus Borrelia, B. afzelii and $B$. garinii have been isolated and identified in Korea (Park et al., 1993). B. afzelii and B. garinii were also found to be the principal Borrelia species in Russia, China and Japan (Sato et al., 1996; Li et al., 1998; Kawabata et al., 1993; Postic et al., 1993).Other species, such as B. japonica, B. turdi and B. tanukii, have been isolated in Japan (Fukunaga et al., 1996; Kawabata et al., 1993). It is therefore not surprising that Borrelia species other than B. afzelii and $B$. garinii were identified in Korea.

However, the Haenam strains showed several interesting characteristics, firstly concerning their tick vector. There is a relationship between Borrelia species and their vectors. For example, B. japonica is associated with Ixodes ovatus. B. turdi and B. tanukii were isolated from Ixodes turdus and Ixodes tanuki in Japan, and ' $B$. andersonii' was associated with Ixodes dentatus in the US. B. burgdorferi sensu lato has so far been isolated from heart and kidney of $A$. agrarius and Ixodes ticks (Ixodes nipponensis and Ixodes persulcatus). Interestingly, Haenam strains were isolated from I. granulatus and A. agrarius in the Haenam area, Korea. I. granulatus is a rare species of tick vector for Lyme spirochaetes. Its relationship with Borrelia has previously been reported only in China (Zhang, 1992).

Secondly, these strains showed RFLP patterns using a 23S rRNA gene probe that differed from those of the other isolates, which had been differentiated and identified as B. afzelii and B. garinii (Park et al., 1998). In this study, Haenam strains were further characterized by PCR-RFLP analysis of the 5S-23S gene, which is a simple, rapid diagnostic tool (Postic et al., 1994). The MseI and DraI restriction patterns of Haenam strains described in this paper were markedly different from those of other B. burgdorferi sensu lato strains reported by other investigators (Postic et al., 1994, 1998; Masuzawa et al., 1996) (Table 1).

To determine the topology of Haenam strains in the phylogenetic relationships among the Borrelia species, we also used 16S rDNA sequence analysis (Marconi \& Garon, 1992; Le Fleche et al., 1997; Wang et al., 1997; Postic et al., 1998). Haenam strains formed a distinctive cluster, separated from other strains of $B$. burgdorferi sensu lato. Haenam strains were closer to $B$. valaisiana and $B$. tanukii than to $B$. afzelii and $B$. garinii, which had been previously isolated and reported in Korea (Park et al., 1993). Furthermore, signature nucleotides in the $16 \mathrm{~S}$ rDNA sequences of Haenam strains enabled us to design specific primers for the rapid identification and differentiation of Haenam strains from other members of B. burgdorferi sensu lato. PCR, with the primers described, can be used for the study of the vector, the reservoir and the geographical distribution of the Haenam strains.

\section{ACKNOWLEDGEMENTS}

This work was supported in part by the Basic Medical Research Fund, Korean Medical Association (1998) to Dr S.-H. Lee.

\section{REFERENCES}

Anderson, J. F. (1989). Epizootiology of Borrelia in Ixodes tick vectors and reservoir hosts. Rev Infect Dis 11, 1451-1459.

Baranton, G., Postic, D., Saint Girons, I., Boerlin, P., Piffaretti, J. C., Assous, M. \& Grimont, P. A. (1992). Delineation of Borrelia burgdorferi sensu stricto, Borrelia garinii sp. nov., and group VS461 associated with Lyme borreliosis. Int J Syst Bacteriol 42, 378-383.

Barbour, A. G. (1984). Isolation and cultivation of Lyme disease spirochetes. Yale J Biol Med 57, 521-525.

Barbour, A. G. (1988). Plasmid analysis of Borrelia burgdorferi, the Lyme disease agent. J Clin Microbiol 26, 475-478. 
Barbour, A. G. \& Garon, C. F. (1987). Linear plasmids of the bacterium Borrelia burgdorferi have covalently closed ends. Science 237, 409-411.

Barbour, A. G., Heiland, R. A. \& Howe, T. R. (1985). Heterogeneity of major proteins in Lyme disease Borreliae: a molecular analysis of North American and European isolates. J Infect Dis 152, 478-484.

Boerlin, P., Peter, O., Bretz, A. G., Postic, D., Baranton, G. \& Piffaretti, J. C. (1992). Population genetic analysis of Borrelia burgdorferi isolates by multilocus enzyme electrophoresis. Infect Immun 60, 1677-1683.

Canica, M. M., Nato, F., du Merle, L., Mazie, J. C., Baranton, G. \& Postic, D. (1993). Monoclonal antibodies for identification of Borrelia afzelii sp. nov. associated with late cutaneous manifestations of Lyme borreliosis. Scand J Infect Dis 25, 441-448.

Fukunaga, M., Hamase, A., Okada, K. \& Nakao, M. (1996). Borrelia tanukii sp. nov. and Borrelia turdae sp. nov. found from ixodid ticks in Japan: rapid species identification by $16 \mathrm{~S}$ rRNA gene-targeted PCR analysis. Microbiol Immunol 40, 877-881.

Johnson, R. C., Schmid, G. P., Hyde, F. W., Steingerwalt, A. G. \& Brenner, D. J. (1984). Borrelia burgdorferi sp. nov.: etiologic agent of Lyme disease. Int J Syst Bacteriol 34, 496-497.

Kawabata, H., Masuzawa, T. \& Yanagihara, Y. (1993). Genomic analysis of Borrelia japonica sp. nov. isolated from Ixodes ovatus in Japan. Microbiol Immunol 37, 843-848.

Kumur, S., Tamura, K. \& Masatoshi, N. (1993). MEGA: molecular evolutionary genetics analysis, version 1.01. The Pensylvania State University, University Park, PA, USA.

Le Fleche, A., Postic, D., Girardet, K., Peter, O. \& Baranton, G. (1997). Characterization of Borrelia lusitaniae sp. nov. by $16 \mathrm{~S}$ ribosomal DNA sequence analysis. Int $J$ Syst Bacteriol 47, 921-925.

Li, M., Masuzawa, T., Takada, N. \& 7 other authors (1998). Lyme disease Borrelia species in northeastern China resemble those isolated from far eastern Russia and Japan. Appl Environ Microbiol 64, 2705-2709.

Marconi, R. T. \& Garon, C. F. (1992). Development of polymerase chain reaction primer sets for diagnosis of Lyme disease and for species-specific identification of Lyme disease isolates by $16 \mathrm{~S}$ rRNA signature nucleotide analysis. J Clin Microbiol 30, 2830-2834.

Marconi, R. T., Liveris, D. \& Schwartz, I. (1995). Identification of novel insertion elements, restriction fragment length poly- morphism patterns, and discontinuous 23S rRNA in Lyme disease spirochetes: phylogenetic analyses of rRNA genes and their intergenic spacers in Borrelia japonica sp. nov. and genomic group 21038 (Borrelia andersonii sp. nov.) isolates. $J$ Clin Microbiol 33, 2427-2434.

Masuzawa, T., Komikado, T., Iwaki, A., Suzuki, H., Kaneda, K. \& Yanagihara, Y. (1996). Characterization of Borrelia sp. isolated from Ixodes tanuki, I. turdus, and I. columnae in Japan by restriction fragment length polymorphism of $r r f(5 \mathrm{~S})-r r l(23 \mathrm{~S})$ intergenic spacer amplicons. FEMS Microbiol Lett 142, 77-83.

Park, K. H., Chang, W. H. \& Schwan, T. G. (1993). Identification and characterization of Lyme disease spirochetes, Borrelia burgdorferi sensu lato, isolated in Korea. J Clin Microbiol 31, 1831-1837.

Park, K. H., Kim, J. H., Hahn, M. J. \& Lee, S. H. (1998). Classification of Borrelia burgdorferi sensu lato isolated in Korea by restriction fragment length polymorphism. J Korean Soc Microbiol 33, 119-128.

Postic, D., Belfaiza, J., Isogai, E., Saint Girons, I., Grimont, P. A. \& Baranton, G. (1993). A new genomic species in Borrelia burgdorferi sensu lato isolated from Japanese ticks. Res Microbiol 144, 467-473.

Postic, D., Assous, M. V., Grimont, P. A. \& Baranton, G. (1994). Diversity of Borrelia burgdorferi sensu lato evidenced by restriction fragment length polymorphism of $r r f(5 \mathrm{~S})-r r l(23 \mathrm{~S})$ intergenic spacer amplicons. Int J Syst Bacteriol 44, 743-752.

Postic, D., Ras, N. M., Lane, R. S., Hendson, M. \& Baranton, G. (1998). Expanded diversity among Californian Borrelia isolates and description of Borrelia bissettii sp. nov. (fomerly Borrelia Group DN127). J Clin Microbiol 36, 3497-3504.

Sato, Y., Miyamoto, K., Iwaki, A. \& 7 other authors (1996). Prevalence of Lyme disease spirochetes in Ixodes persulcatus and wild rodents in far eastern Russia. Appl Environ Microbiol 62, 3887-3889.

Steere, A. C. (1989). Lyme disease. $N$ Engl J Med 321, 586-596.

Wang, G., van Dam, A. P., Le Fleche, A., Postic, D., Peter, O., Baranton, G., de Boer, R., Spanjaard, L. \& Dankert, J. (1997). Genetic and phenotypic analysis of Borrelia valaisiana sp. nov. (Borrelia genomic groups VS116 and M19). Int J Syst Bacteriol 47, 926-932.

Zhang, Z. (1992). Survey on tick vectors of Lyme disease spirochetes in China. Chung Hua Liu Hsing Ping Hsueh Tsa Chih 13, 271-274. 